\title{
Infection Caused by Phaeomoniella chlamydospora Associated with Esca-like Symptoms in Grapevine in Chile
}

Gonzalo A. Díaz and Bernardo A. Latorre, Departamento de Fruticultura y Enología, Facultad de Agronomía e Ingeniería Forestal, Pontificia Universidad Católica de Chile, Vicuña Mackenna 4860, Macul, Santiago, Chile

\begin{abstract}
Díaz, G. A., and Latorre, B. A. 2014. Infection caused by Phaeomoniella chlamydospora associated with esca-like symptoms in grapevine in Chile. Plant Dis. 98:351-360.

Trunk diseases such as esca have been recognized as an economically important problem of grapevine worldwide. A study was conducted to characterize the distribution of Phaeomoniella chlamydospora in Chile. A field survey of young and mature grapevines from 67 vineyards located along a $1,315-\mathrm{km}$ north-south axis demonstrated that $P$. chlamydospora was present in $94.9 \%$ of the grapevine samples showing the black-wood streaking symptom (BWS) but not the characteristic foliar symptoms of esca. Phylogenetic analysis of the ribosomal DNA internal transcribed spacer (ITS) combined with $\beta$-tubulin (BT) genes grouped Chilean isolates together with reference isolates from South Africa and the United States, whereas Spanish isolates were

clustered separately. Chilean isolates differed by only 2 to $3 \mathrm{bp}$ for BT and ITS, respectively. Conidia germinated at 5 to $35^{\circ} \mathrm{C}$, with an optimal temperature of 25 to $30^{\circ} \mathrm{C}$. Isolates were pathogenic, and Koch's postulates were fulfilled in separate sets of inoculations of axenic plantlets, cuttings, 2-year-old plants, spurs, and shoots of $V$. vinifera. This study showed that $P$. chlamydospora was associated consistently with BWS and no other apparent symptom in young and mature grapevines, including nursery plants, in Chile. Inoculum was absent from the soil, grapevine pruning debris, sap samples, and herbaceous weeds, which is in contrast to past studies. At this time, Vitis spp. are the only known hosts of $P$. chlamydospora in Chile.
\end{abstract}

In Chile, grapevines (Vitis vinifera L.) are planted on 182,000 ha of land, with vineyards distributed over $1,300 \mathrm{~km}$ along a northsouth axis throughout diverse climate and soil conditions. Trunk diseases have been recognized as an economically important problem that considerably reduces the productive life of vineyards in Chile and throughout the world (47). Trunk pathogens Phaeomoniella chlamydospora (W. Gams, Crous, M.J. Wingf. \& Mugnai) Crous \& W. Gams and several other filamentous fungi, including species of Botryosphaeriaceae, Diatrypaceae, Phaeoacremonium, Fomitiporia, and Inocutis, have been associated with many different trunk diseases $(3,15,16,37,40,47,48,51)$. In Chile, Botryosphaeria dieback $(9,22)$, black dead arm, and basal canker (7) have been reported. In addition, chlorotic leaf roll similar to $\mathrm{Eu}-$ typa dieback has been recognized in Chile (6).

$P$. chlamydospora has been associated with esca in mature grapevines ( $>7$-year-old) and with petri disease in relatively young (<7-year-old) grapevines. The most consistent symptom associated with $P$. chlamydospora infection is dark-brown to black discoloration of xylem tissue in the wood (black-wood streaking [BWS]). Additional symptoms include mild chlorosis, stunted leaves, short internodes, and lack of vigor in young grapevines whereas, in older plants, external symptoms are characterized by a general decline and stunted growth, chlorotic and malformed leaves, partial necrosis of the leaf blade, short internodes, and often death of spurs and slow decline $(25,36,37,40,44)$.

The sources of inoculum are not clear. Rooney et al. (43) found $P$. chlamydospora in sap samples obtained from girdling wounds and from bark debris of grapevines collected near the soil line but they were unable to isolate the pathogen from soil samples in the vineyard. However, P. chlamydospora has been detected, albeit by a DNA-based method, in nursery soil (42). Recently, P. chlamydospora was reported from olive (Olea europaea) (49), kiwifruit

Corresponding author: B. A. Latorre, E-mail: blatorre@uc.cl

Accepted for publication 11 September 2013.

http://dx.doi.doi/10.1094/PDIS-12-12-1180-RE

(C) 2014 The American Phytopathological Society
(Actinidia deliciosa) (23), and bindweed (Convolvulus arvensis) (1), suggesting that other hosts may serve as a reservoir of inoculum from infection of grapevine.

In Chile, $P$. chlamydospora has been associated with decline symptoms (8) and it is the most frequently isolated pathogen from grapevines with internal BWS in the cordons and trunks. It is often associated with grapevine decline (20). However, further research is needed for a better understanding of the relative role of $P$. chlamydospora among trunk pathogens in Chile. This study expands on the results of a previous study (8), with the objective of characterizing and determining the relative importance of $P$. chlamydospora in vineyards affected by esca-like symptoms.

\section{Materials and Methods}

Field survey and fungal isolation. The surveys were conducted in 2009 to 2011 in 67 vineyards with disease incidence varying from 0.0 to $92.3 \%$. Vineyards were located along a $1,315-\mathrm{km}$ north-south axis $\left(30^{\circ} 42^{\prime} \mathrm{S}\right.$ to $\left.37^{\circ} 42^{\prime}\right)$ across a range of diverse soil and climatic conditions, with a mean annual rainfall of 1 to 1,000 $\mathrm{mm}$, most of which fell during the winter months (Fig. 1). All of the vineyards were located at relatively low altitudes. In each vineyard, 8 to 12 cordon or trunk samples were taken from grapevines affected with BWS symptoms, some of which exhibited yellow softwood decay or brown hardwood decay. The samples were surface disinfected (96\% ethanol, $15 \mathrm{~s}$ ) and flamed for $2 \mathrm{~s}$. Small wood pieces ( 3 to $5 \mathrm{~mm}$ in length) were taken from the (i) BWS, (ii) yellow softwood decay, and (iii) brown hardwood decay (Fig. 2A) and placed on $2 \%$ acidified potato dextrose agar (APDA) that was modified with $0.005 \%$ tetracycline, $0.01 \%$ streptomycin, and $0.1 \%$ Igepal CO-630 (APDAm; Sigma-Aldrich). Cultures were incubated for 21 days at $20^{\circ} \mathrm{C}$ unless otherwise stated. Subcultures were obtained from green olivaceous colonies with white to yellow margins that slowly emerged from wood pieces on the APDAm plates. Pure cultures were obtained by transferring hyphal tips onto APDA and were maintained at $20^{\circ} \mathrm{C}$ for further study.

In total, 105 grapevine spurs from 'Cabernet Sauvignon' $(n=$ $45)$ 'Carménère' $(n=10)$, 'Chardonnay' $(n=20)$, and 'Pinot Noir' $(n=30)$ were sampled just after pruning (July to August) in four commercial vineyards in Alto Jahuel $(n=30)$, Buin $(n=15)$, Casablanca $(n=50)$, and Nancagua $(n=10)$ in 2011 and 2012. The spur 
surfaces were disinfected, and small fragments (3 to $5 \mathrm{~mm}$ ) were placed in APDAm and incubated as indicated above.

Isolations from grapevine nurseries were conducted in 151 samples of rooted cuttings ( $<2$ years old) of Cabernet Sauvignon $(n=$ $60)$, Carménère $(n=25)$, Chardonnay $(n=35)$, and Pinot Noir $(n=$ 31) obtained from four commercial nurseries located in Buin $\left(33^{\circ} 43^{\prime} \mathrm{S}\right)$, Casablanca $\left(33^{\circ} 22^{\prime} \mathrm{S}\right)$, Paine $\left(33^{\circ} 48^{\prime} \mathrm{S}\right)$, and Pirque $\left(33^{\circ} 37^{\prime}\right.$ S) from 2010 to 2012 . Sample surfaces were disinfected, and the wood pieces that were affected by BWS symptoms were taken from the cuttings and placed in APDAm as described above.

Potential inoculum sources. In total, 168 samples of grapevine pruning debris ( $>2$ years old) from Cabernet Sauvignon $(n=90)$, Carménère $(n=20)$, Chardonnay $(n=18)$, and Pinot Noir $(n=40)$ were randomly selected from the ground in six commercial vine- yards from 2009 to 2011. They were examined for the presence of Phaeomoniella spp. under a stereoscopic microscope, and samples of wood tissue were plated onto APDAm as described above.

Sap-sample isolations were attempted from grapevines with wood streaking $(n=82)$ and apparently healthy Cabernet Sauvignon $(n=47)$ Chardonnay $(n=10)$, 'Merlot' $(n=5)$, Pinot Noir $(n$ $=10)$, and 'Syrah' $(n=10)$ from Alto Jahuel, Buin, Casablanca, and Nancagua ( $n=68$ total apparently healthy vines). Sap samples $(1.0 \mathrm{ml} / \mathrm{vine})$ were obtained with aid of sterile hypodermic syringe between bud burst and the appearance of two to three unfolded leaves in late August of 2010 and 2011, when pruning cuts were bleeding. Aliquots $(10 \mu \mathrm{l})$ were observed under a light microscope, and $100 \mu \mathrm{l}$ of sap was plated in triplicate on APDAm plates. The plates were incubated at $20^{\circ} \mathrm{C}$ for 21 days.

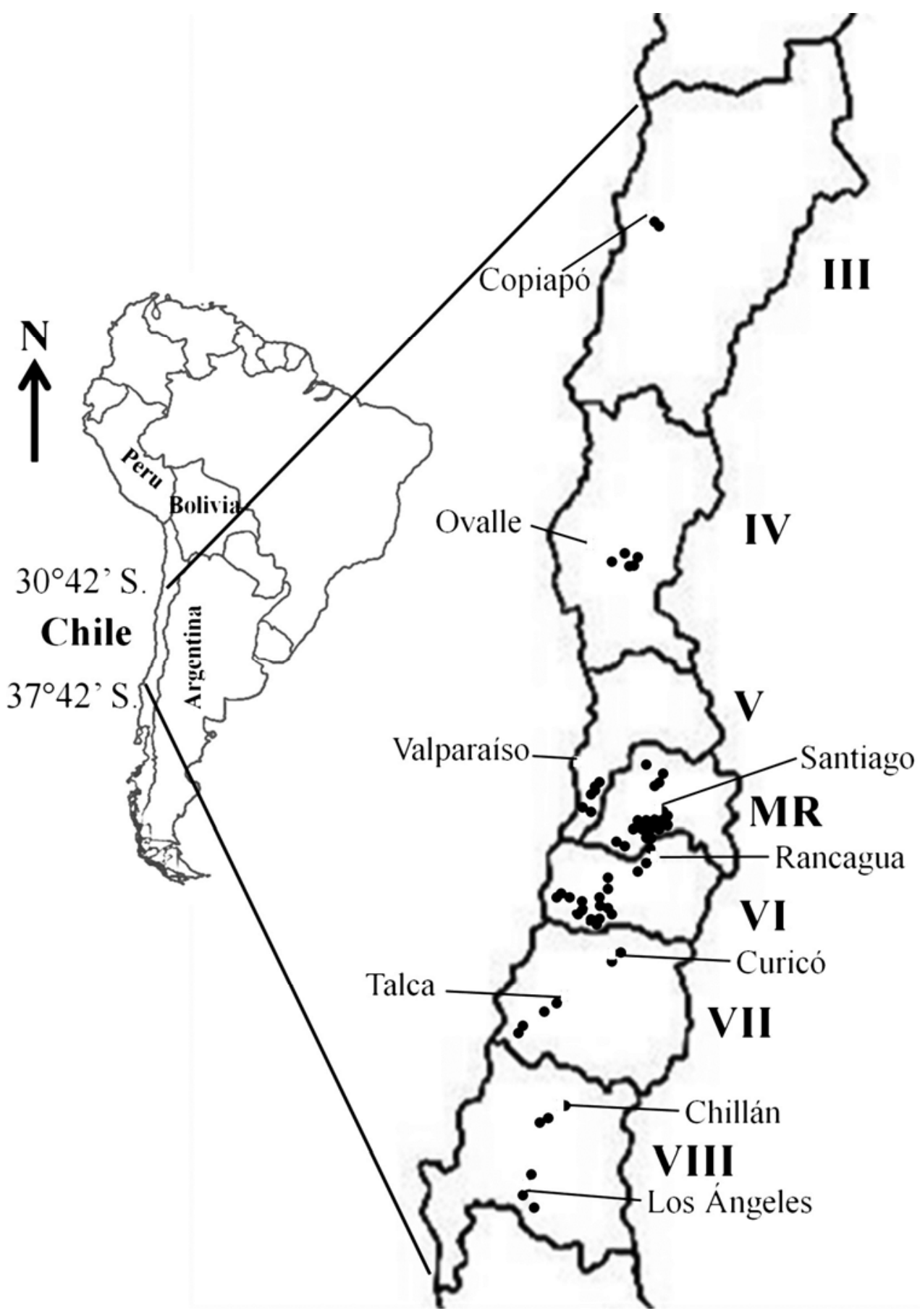

Fig. 1. Map of Chile showing the administrative regions and major cities where grapevines were sampled in this study. Each of 67 black points indicate the geographical location of the surveyed vineyards. III: Atacama Region; IV: Coquimbo Region; V: Valparaíso Region; MR: Metropolitan Region; VI: Libertador General Bernardo O'Higgins Region; VII: Maule Region; VIII: Bío-Bío Region. 
Isolation of $P$. chlamydospora was attempted from soil samples $(50 \mathrm{~g})$ taken from the upper $5 \mathrm{~cm}(n=20)$ and at a depth of $20 \mathrm{~cm}$ $(n=80)$ from six vineyards, planted in loam, sandy loam, and clay soils in central Chile. All samples were obtained $10 \mathrm{~cm}$ away from the trunk of vines with BWS symptoms. Each sample was suspended in $300 \mathrm{ml}$ of $0.05 \%$ Tween 80 in sterile water and agitated for $48 \mathrm{~h}$ at $20^{\circ} \mathrm{C}$, and $100 \mu \mathrm{l}$ were plated on petri plates containing the semiselective medium of Rooney et al. (43) but without Rose Bengal and modified to include $0.01 \%$ streptomycin and $0.1 \%$ Igepal CO-630.

The presence of $P$. chlamydospora was studied in weeds commonly found in vineyards $(n=293)$, including Brassica rapa $(n=$ 33), C. arvensis $(n=20)$, Cynodon dactylon $(n=20)$, Erodium moschatum $(n=5)$, Malva sylvestris $(n=135)$, Portulaca oleracea $(n=40)$, and Raphanus raphanistrum $(n=40)$. Weeds were collected from vineyards with grapevines with the BWS symptom. Samples were surface disinfected prior to cutting off small pieces of roots and stems, which were plated on APDAm as described above.

Morphology and growth studies. Phaeomoniella isolates were identified on the basis of colony morphology and conidial or conidiophore characteristics (16). The color and growth pattern of colonies growing on APDA and 2\% malt extract agar (MEA) media were recorded after 21 days of incubation at $25^{\circ} \mathrm{C}$. Eight representative isolates were plated on autoclaved pine needles and autoclaved grapevine wood chips that were aseptically placed in $1.5 \%$ water agar (WA) to enhance sporulation. Cultures were incubated for 21 days at $25^{\circ} \mathrm{C}$ under near-UV light with a 12 -h photoperiod, and then at $10^{\circ} \mathrm{C}$ for an additional 28 days under darkness. Cultures were examined weekly for pycnidia and conidia production. Conidia and conidiophore morphology and size $(n=30)$ were determined. Additionally, $0.5-\mathrm{cm}^{2}$ samples of Phaeomoniella isolates were taken for a scanning electron microscope (SEM) image from colonies that had been growing in APDA for 28 days, and the samples were processed as previously described (11). Samples were observed in a LEO 1420 VP SEM (LEO Electron Microscopy Ltd.).

The effect of temperature on conidial germination and mycelial growth was determined for $P$. chlamydospora isolates Pach-3,
Pach-32, Pach-36, Pach-55, Pach-59, Pach-155, Pach-297, and Pach-304, which were incubated at $0,5,10,15,20,25,30,35$, and $40^{\circ} \mathrm{C}$ in incubation chambers (Velp). The inside temperature of the chambers was verified with HOBO PRO temperature sensors (Onset Computed Corp.).

Conidia were obtained from 21-day-old APDA cultures, and 100 $\mu \mathrm{l}$ of a conidial suspension $\left(10^{6}\right.$ conidia/ml $)$ was placed on petri dishes containing 2\% WA. Germination was determined after 2, 4 , $6,12,24$, and $48 \mathrm{~h}$ of incubation, and at least 100 conidia per isolate were examined. Conidia were considered to be germinated if the length of the germ tube was at least twice the length of the spore. The effect of temperature on mycelial growth was studied on APDA plates that were inoculated with a mycelium plug $(5 \mathrm{~mm}$ in diameter) that was obtained from 21-day-old colonies on APDA. Plates were incubated at the temperature indicated above for 14 days prior to the determination of radial mycelia growth. The APDA cultures were incubated at $25^{\circ} \mathrm{C}$ for 28 days, and measurements were taken every week to determine the fungal growth rate. The two experiments were analyzed within an eight-by-nine factorial design (isolate by temperature) with four replicates. Dates were analyzed for variance, and the means were separated according to Tukey's test $(P<0.05)$ using SigmaStat 3.1 (Systat Software Inc.).

Phylogenetic analysis. Species-level identification was carried out, in part, through phylogenetic analyses of the 22 representative Phaeomoniella isolates obtained from BWS symptoms in vineyards. These isolates were selected by geographic origins and grapevine cultivars (Table 1). Comparisons were made to sequences of isolates of $P$. chlamydospora available from the GenBank database (Table 2). Analyses included sequences of internal transcribed spacer (ITS) and $\beta$-tubulin (BT) nuclear loci of seven isolates of $P$. chlamydospora as reference: CBS 229.95 (exholotype), STE-U3066, UCD2557AR, UCD2586MO, Y83-8-1, Y86-10-1, and Y121-20-1. Also, other sequences of Phaeomoniella spp. available for ITS from the GenBank database were included, with the purpose of knowing their presence in Chilean Phaeomoniella isolates.

DNA of 22 Chilean isolates of Phaeomoniella was extracted from 30 to $50 \mathrm{mg}$ of mycelium on 21-day-old APDA cultures using
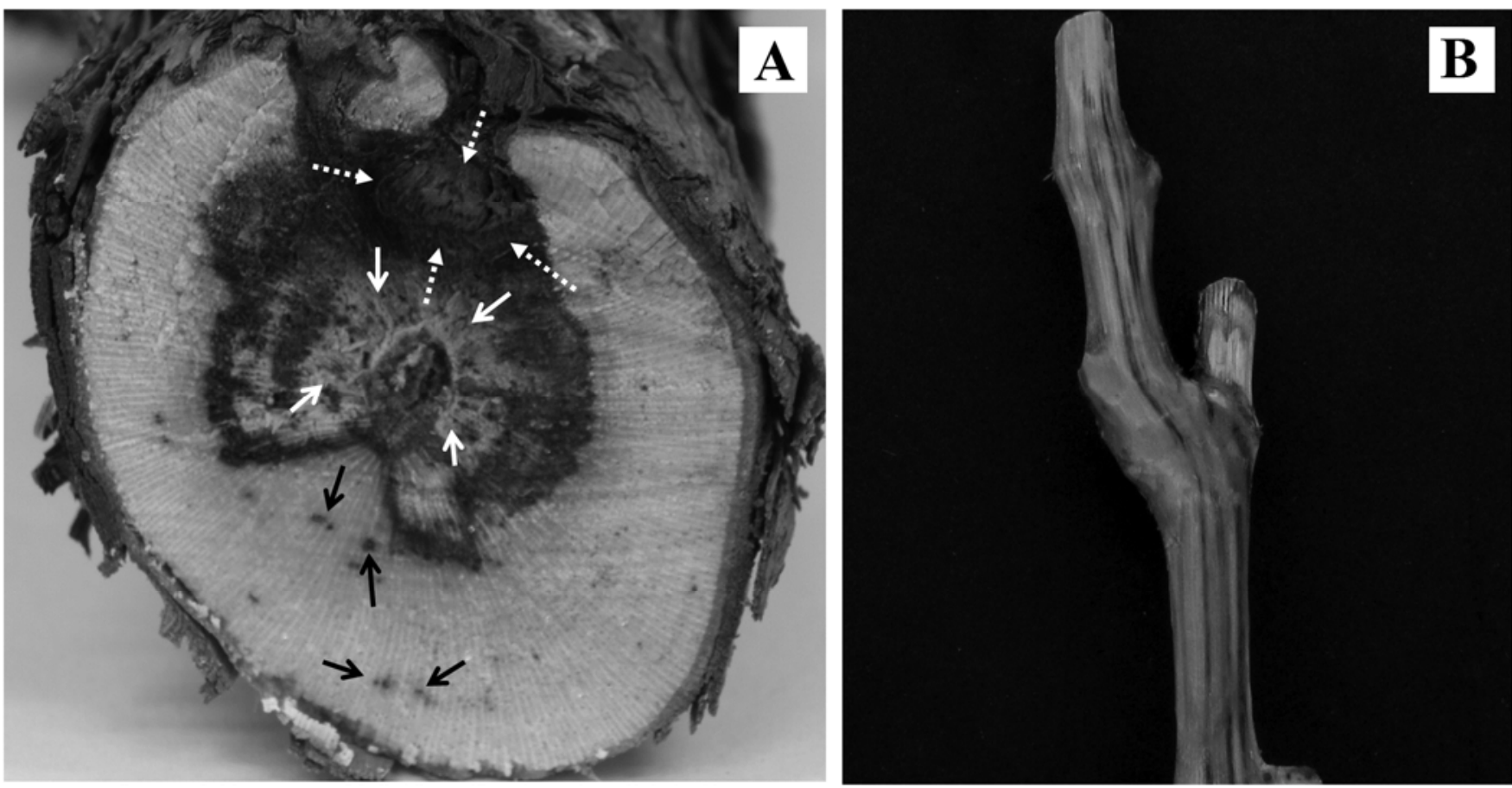

Fig. 2. A, Example of cross section of a 'Cabernet Sauvignon' trunk (15 years old) showing black spots (black arrows), which appear as black wood-streaking in longitudinal section, yellow soft decay (white arrows), and brown hard decay (white point-arrows) on the wood of grapevines with trunk diseases (Vitis vinifera). Isolations were performed on modified acidified potato dextrose agar and incubated at $20^{\circ} \mathrm{C}$ for 21 days. B, Cabernet Sauvignon grapevine spur with black wood-streaking. 
the AxyPrep Multisource Genomic DNA Miniprep Kit (Axygen Biosciences).

For all Chilean isolates of Phaeomoniella, two nuclear loci (polymerase chain reaction [PCR] primer follows in parentheses) were sequenced from a 482- to 586-bp section of the nuclear ribosomal DNA of ITS region ITS1-5.8S-ITS2 (ITS4 and ITS5) (52), and from a 353- to 406-bp section of a portion of BT (Bt2a and $\mathrm{Bt} 2 \mathrm{~b}$ ) (30). The PCR mixture contained $2.5 \mu \mathrm{l}$ of $10 \times$ PCR buffer, $1.0 \mu \mathrm{l}$ of $25 \mathrm{mM} \mathrm{MgCl}_{2}, 0.5 \mu \mathrm{l}$ of $10 \mathrm{mM}$ dNTPs, $0.5 \mu \mathrm{l}$ of $0.5 \mathrm{mM}$ each primer, $0.2 \mu \mathrm{l}$ of Taq DNA polymerase (Invitrogen) at 5 units $/ \mu \mathrm{l}$, and $1 \mu \mathrm{l}$ of template DNA in a final volume of $25 \mu \mathrm{l}$. A control sample without DNA was included. The PCRs were performed using a Maxygen Gradient thermal cycler (Axygen Biosciences) with cycling parameters of $94^{\circ} \mathrm{C}$ for $2 \mathrm{~min} ; 35$ cycles at $94^{\circ} \mathrm{C}$ for $1 \mathrm{~min}, 58^{\circ} \mathrm{C}$ for $1 \mathrm{~min}$, and $72^{\circ} \mathrm{C}$ for $1.5 \mathrm{~min}$; and a cycle at $72^{\circ} \mathrm{C}$ for $10 \mathrm{~min}$. The presence and size of amplicons was confirmed by gel electrophoresis of $2 \%$ agarose $(100 \mathrm{~V}$, $30 \mathrm{~min}$ ) in $1.0 \times$ Tris-acetate-EDTA buffer stained with GelRed (Biotium Inc.) and visualized by UV $(\lambda=302 \mathrm{~nm})$ transillumination. The PCR products were purified and sequenced in both directions by Macrogene Inc.. All sequences were edited manually using the Bio Edit sequence alignment editor (v. 7.1.3.0; Tom Hall, Isis Pharmaceutical Inc.), and ambiguous re- gions on both sides of the sequences were excluded from the analysis.

A partition homogeneity test conducted in PAUP (version 4.0b10; Sinauer Associates) was not significant; therefore, a joint analysis of the ITS and BT datasets was conducted. Gaps were treated as a fifth character weight, and all characters were unordered and of an equal weight. A maximum parsimony (MP) was performed with Molecular Evolutionary Genetics Analysis (version 5) software (45), using the heuristic search option, and 1,000 random addition sequence replicates were used. The bootstrap values were evaluated by using 1,000 replicates to test the branch strength. The tree length (TL), consistency index (CI), retention index (RI), and rescaled consistency index (RC) were also recorded. A Neofusicoccum australe sequence was used as the outgroup (GenBank accession numbers JX290091 and JX679868 for ITS and BT, respectively).

Pathogenicity tests. We conducted a series of pathogenicity tests on different tissues. To determine the proper concentration of conidia for pathogenicity tests, we inoculated detached Cabernet Sauvignon canes of $25 \mathrm{~cm}$ in length. Canes were wounded ( $3 \mathrm{~mm}$ ) with a sterile scalpel in the middle of the cane prior to being inoculated them with $20 \mu \mathrm{l}$ of conidial suspensions of $P$. chlamydospora isolate Pach-3 adjusted to $10^{2}, 10^{5}$, and $10^{7}$ conidia/ml. The control

Table 1. Vitis vinifera isolates of Phaeomoniella chlamydospora from Chile that were used for this study

\begin{tabular}{|c|c|c|c|c|}
\hline \multirow[b]{2}{*}{ Isolates } & \multirow[b]{2}{*}{ Host cultivars } & \multirow[b]{2}{*}{ Origins } & \multicolumn{2}{|c|}{ GenBank accession number } \\
\hline & & & ITS $^{\mathbf{y}}$ & $\beta$-Tubulin \\
\hline Pach- $3^{z}$ & Cabernet Sauvignon & Alto Jahuel & JF968607 & JX679890 \\
\hline Pach-6 & Cabernet Sauvignon & Alhué & JQ822226 & JX679889 \\
\hline Pach-7 & Cabernet Sauvignon & Alhué & JQ822225 & JX679888 \\
\hline Pach-25 & Merlot & Alto Jahuel & JQ822224 & JX679887 \\
\hline Pach-32 & Pinot Noir & Casablanca & JQ822223 & JX679886 \\
\hline Pach-36 & Pinot Noir & Casablanca & JQ822222 & JX679885 \\
\hline Pach-50 & Cabernet Sauvignon & Nancagua & JQ822221 & JX679884 \\
\hline Pach-55 & Pinot Noir & Mulchén & JF968608 & JX679883 \\
\hline Pach-59 & Sauvignon blanc & Mulchén & JQ822220 & JX679882 \\
\hline Pach-89 & Chardonnay & Casablanca & JQ822219 & JX679881 \\
\hline Pach-102 & Thompson Seedless & Paine & JQ822218 & JX679880 \\
\hline Pach-105 & Cabernet Sauvignon & Pirque & JQ822217 & JX679879 \\
\hline Pach-128 & Carménère & Apalta & JQ822216 & JX679878 \\
\hline Pach-132 & Chardonnay & Casablanca & JQ822215 & JX679877 \\
\hline Pach-155 & Cabernet Sauvignon & Alto Jahuel & JQ822214 & JX679876 \\
\hline Pach-230 & Red Globe & Colina & JQ822213 & JX679875 \\
\hline Pach-297 & Chardonnay & Ovalle & JQ822212 & JX679874 \\
\hline Pach-300 & Cabernet Sauvignon & Nancagua & JQ822211 & JX679873 \\
\hline Pach-302 & Cabernet Sauvignon & Cauquenes & JQ822210 & JX679872 \\
\hline Pach-304 & Cabernet Sauvignon & Cauquenes & JQ822209 & JX679871 \\
\hline Pach-394 & Cabernet Sauvignon & Ovalle & JQ822208 & JX679870 \\
\hline Pach-525 & Syrah & Nancagua & JQ822207 & JX679869 \\
\hline
\end{tabular}

y Internal transcribed spacer.

${ }^{\text {z }}$ Isolate Pach-3 was deposited as IMI number 397989 at the Commonwealth Agricultural Bureaux International (CABI, Egham, Surrey, UK).

Table 2. Reference isolates of Phaeomoniella chlamydospora and other species of Phaeomoniella used in the phylogenetic analysis obtained from GenBank

\begin{tabular}{|c|c|c|c|c|c|}
\hline \multirow[b]{2}{*}{ Species } & \multirow[b]{2}{*}{ Strain } & \multirow[b]{2}{*}{ Host } & \multicolumn{2}{|c|}{ GenBank accession number } & \multirow[b]{2}{*}{ Reference } \\
\hline & & & ITS & $\beta$-Tubulin & \\
\hline P. chlamydospora & CBS $229.95^{z}$ & Vitis vinifera & AF197973 & AF253968 & 32 \\
\hline P. chlamydospora & STE-U 3066 & $V$. vinifera & AF197986 & AF253969 & 32 \\
\hline P. chlamydospora & UCD2557AR & $V$. vinifera & HQ288242 & HQ288314 & 48 \\
\hline P. chlamydospora & UCD2586MO & $V$. vinifera & HQ288244 & HQ288316 & 48 \\
\hline P. chlamydospora & Y83-8-1 & $V$. vinifera & EU018412 & EU078329 & 13 \\
\hline P. chlamydospora & Y86-10-1 & $V$. vinifera & EU018413 & EU078334 & 13 \\
\hline P. chlamydospora & Y121-20-1 & $V$. vinifera & EU018417 & EU078333 & 13 \\
\hline P. dura & STE-U 6122 & Prunus salicina & GQ154597 & - & 17 \\
\hline Phaeomoniella effusa & STE-U 6121 & Prunus salicina & GQ154598 & - & 17 \\
\hline Phaeomoniella prunicola & STE-U 6118 & Prunus salicina & GQ154590 & - & 17 \\
\hline Phaeomoniella prunicola & STE-U 6347 & Prunus salicina & GQ154594 & - & 17 \\
\hline Phaeomoniella tardicola & STE-U 6123 & Prunus armeniaca & GQ154599 & - & 17 \\
\hline Phaeomoniella zymoides & STE-U 6120 & Prunus salicina & GQ154600 & - & 17 \\
\hline
\end{tabular}

y ITS = internal transcribed spacer; - = not available in GenBank.

${ }^{\text {z }}$ Ex-type culture. 
treatment was sterile water. The inoculated wounds were sealed with Parafilm to avoid dehydration. Canes were inserted at a $60^{\circ}$ angle into humid perlite $(4 \mathrm{~cm}$ in height) placed at the bottom of polyethylene humidity chamber ( $>85 \%$ relative humidity, 35 by 27 by $13 \mathrm{~cm})$. To avoid a rapid dehydration of the canes, a water $(2$ $\mathrm{cm}$ in height) was maintained at the bottom of the chambers. Canes were incubated at $25^{\circ} \mathrm{C}$ for 45 days prior to determine the BWS lengths. Reisolations from stem tissues and the margins of BWS lesions were performed on APDAm and incubated at $20^{\circ} \mathrm{C}$ for 14 days. The data were analyzed for variance according to a completely randomized design with eight replicates. Means were separated according to Tukey's test $(P<0.05)$ using SigmaStat.

The first pathogenicity test was conducted on eight axenic plantlets of $V$. vinifera Carménère from 30-day-old micropropagated nodal explants that were grown on semisolid medium. The plantlets were inoculated with P. chlamydospora isolates Pach-3, Pach32, Pach-55, and Pach-297. A 3-mm-diameter mycelia plug from a 21-day-old APDA culture or $10 \mu \mathrm{l}$ of conidial suspension $\left(10^{5}\right.$ conidia/ml) of sporulating isolates obtained from a 21-day-old APDA culture were inoculated to a small wound (1 to $2 \mathrm{~mm}$ ) made at the base of the stem with a sterile scalpel. The plantlets were incubated under white fluorescent light at $200 \mu \mathrm{mol} / \mathrm{m}^{2} / \mathrm{s}$ for a $16 \mathrm{~h}$ photoperiod for 28 days at $20^{\circ} \mathrm{C}$. At 28 days post inoculation, numbers of asymptomatic and reddish leaves were counted, and shoot and root length was measured. Equal numbers of plantlets were included as noninoculated controls, using sterile agar or sterile water. Recovery of the pathogen from the plantlets on APDAm was attempted from the margins of colonized tissue. An analysis of variance (ANOVA) was used to test the effect of isolate on recovery of the pathogen. For significant effects, treatment means were separated according with Tukey's test $(P<0.05)$ using SigmaStat. The experiment was conducted twice.

The second pathogenicity test was conducted on rooted 2-yearold $V$. vinifera Carménère, which was planted in a mixture of peat (70\%) and perlite (30\%) in 3.5-liter containers and incubated in the lathe house. Plants were inoculated in June (winter) with $P$. chlamydospora isolates Pach-3, Pach-32, Pach-55, and Pach-297. Five plants per isolate were inoculated with a 5-mm mycelial plug, which was aseptically inserted into the trunk and sealed as described above, and arranged in a completely randomized design in the lathe house. The length of the BWS symptoms was determined after 15 months. Reisolations from the margins of the wood-streaking were performed on APDAm. Grapevines inoculated with sterile agar plugs served as negative controls. An ANOVA was used to test the effect of isolate on length of the BWS symptom. The means were separated according to Tukey's test $(P<0.05)$ using SigmaStat.

The third pathogenicity test was conducted on spurs. Fresh pruning wounds were aseptically produced in 8-year-old Cabernet Sauvignon grapevines and planted on their own roots near Santiago. The vines were inoculated in July (winter) by placing a 5-mmdiameter mycelium plug from $P$. chlamydospora (isolates Pach-3 and Pach-55) as described above or by placing $10 \mu \mathrm{l}$ of a $10^{6} \mathrm{co}-$ nidia/ml suspension on each pruning wound. Wounds were wrapped with Parafilm to avoid rapid dehydration. The length of wood streaking that developed at the inoculation site was evaluated after 8 months. Plants that were inoculated with sterile agar plugs were used as controls. Reisolations were performed from small fragments of wood-streaking tissues that were placed in APDAm. The resulting data were analyzed for variance according to a completely randomized design with five replicates each for one plant with four inoculated spurs. The means were separated according to Tukey's test $(P<0.05)$ using SigmaStat.

The fourth pathogenicity test was conducted on green shoots. Green shoots of Cabernet Sauvignon ( 8 years old) were aseptically wounded ( 3 by $5 \mathrm{~mm}$ ) at the third internode and inoculated with mycelial plugs of $P$. chlamydospora (Pach-3, Pach-32, Pach-55, and Pach-297 isolates) and wrapped as described above in November (spring). Internal black streaking was determined 60 days after the inoculation. Equal numbers of shoots were inoculated with sterile agar plugs as controls. Reisolations were performed from small fragments of black vascular tissues that were placed in APDAm. The data were analyzed for variance according to a completely randomized design with three replicates. The experimental

Table 3. Frequency of isolation of Phaeomoniella chlamydospora obtained from Vitis vinifera in the main grapevine production valleys of Chile

\begin{tabular}{|c|c|c|c|c|c|c|c|c|}
\hline \multirow[b]{2}{*}{ Valley $^{u}$} & \multicolumn{2}{|c|}{ P. chlamydospora } & \multicolumn{6}{|c|}{ Numbers of isolates ${ }^{t}$} \\
\hline & Vineyards $^{\mathrm{v}}$ & Samples $^{w}$ & $\mathbf{A}$ & B & Bot $^{x}$ & Inoc & $\operatorname{Dia}^{y}$ & Others $^{\mathrm{z}}$ \\
\hline \multicolumn{9}{|l|}{$\overline{\mathrm{CT}}$} \\
\hline Copiapó & $0 / 2$ & $0 / 16$ & 0 & 0 & 14 & 6 & 0 & 0 \\
\hline Limarí & $4 / 5$ & $58 / 68$ & 28 & 30 & 12 & 9 & 0 & 7 \\
\hline Aconcagua & $3 / 4$ & $32 / 40$ & 12 & 20 & 18 & 13 & 0 & 0 \\
\hline Casablanca & $4 / 4$ & $35 / 40$ & 12 & 23 & 59 & 35 & 8 & 0 \\
\hline San Antonio & $2 / 2$ & $19 / 26$ & 14 & 5 & 2 & 0 & 0 & 0 \\
\hline Maipo & $19 / 19$ & $168 / 182$ & 58 & 110 & 88 & 85 & 12 & 5 \\
\hline Cachapoal & $3 / 3$ & $33 / 36$ & 14 & 19 & 35 & 25 & 5 & 0 \\
\hline Colchagua & $14 / 16$ & $141 / 160$ & 38 & 103 & 109 & 91 & 9 & 1 \\
\hline Curicó & $1 / 2$ & $12 / 20$ & 5 & 7 & 15 & 24 & 0 & 7 \\
\hline Maule & $3 / 4$ & $35 / 40$ & 7 & 28 & 28 & 35 & 0 & 0 \\
\hline Itata & $2 / 2$ & $21 / 22$ & 8 & 13 & 7 & 12 & 0 & 0 \\
\hline Bío-Bío & $3 / 4$ & $36 / 44$ & 10 & 26 & 4 & 3 & 0 & 0 \\
\hline Subtotal (CT) & $58 / 67$ & $590 / 694$ & 206 & 384 & 391 & 338 & 34 & 20 \\
\hline \multicolumn{9}{|l|}{ Spur } \\
\hline Casablanca & $1 / 1$ & $4 / 50$ & 3 & 1 & 1 & 0 & 0 & 0 \\
\hline Maipo & $2 / 2$ & $4 / 45$ & 4 & 0 & 1 & 0 & 0 & 0 \\
\hline Colchagua & $1 / 1$ & $1 / 10$ & 1 & 0 & 0 & 0 & 0 & 0 \\
\hline Subtotal (Spur) & $4 / 4$ & $9 / 105$ & 8 & 0 & 2 & 0 & 0 & 0 \\
\hline Total (CT + Spur) & $62 / 71$ & $599 / 799$ & 214 & 385 & 393 & 338 & 34 & 20 \\
\hline
\end{tabular}

${ }^{\mathrm{t}} \mathrm{A}=$ number of wood samples from which $P$. chlamydospora was the only pathogen isolated and $\mathrm{B}=$ number of samples from which $P$. chlamydospora was isolated together with Botryosphaeriaceae spp. (Bot), Inocutis sp. (Inoc), Diatrypaceae spp. (Dia), and other fungi (Other) associated with trunk diseases.

" Valleys were sorted by geographical location from north to south of Chile. CT $=$ cordon and trunk isolations and Spur $=$ spur isolations.

${ }^{v}$ Number of vineyards from which $P$. chlamydospora was detected/total number of vineyards.

${ }^{\mathrm{w}}$ Number of cordon and trunk or spur samples from which P. chlamydospora was detected/total number of cordon and trunk or spur samples.

${ }^{x}$ Botryosphaeriaceae spp., in order of importance: Diplodia seriata, Spencermartinsia viticola, Neofusicoccum parvum, and Dothiorella sarmentorum. Indicated as number of isolates obtained.

${ }^{\text {y }}$ Diatrypaceae spp., in order of importance: Eutypella leprosa and Cryptovalsa ampelina. Indicated as number of isolates obtained.

${ }^{\mathrm{z}}$ Other fungi species, in order of importance: Seimatosporium botan, Phomopsis viticola, Phaeoacremonium aleophilum, and Cylindrocarpon sp. Indicated as number of isolates obtained. 
unit consisted of four shoots distributed throughout one vine. The means were separated according to the pairwise multiple comparison Tukey's test $(P<0.05)$ using SigmaStat 3.1. The experiment was repeated once.

To compare pathogenicity on two different Vitis spp., detached green shoots ( $15 \mathrm{~cm}$ in length) of $V$. champinii 'Ramsey' and $V$. riparia $\times V$. rupestris 'Schwarzmann' were obtained from commercial orchards. The shoots were surface disinfected as described above. Inoculations were performed by inserting a mycelium plug of 3 by $5 \mathrm{~mm}$ that was taken from 21-day-old APDA cultures of $P$. chlamydospora isolates Pach-3 and Pach-55 into an aseptically produced wound in the middle of each of five shoots per isolate. The wounds were sealed with Parafilm to avoid rapid dehydration. Shoots were incubated in humid chambers (relative humidity $>$ $95 \%$ ) at $20^{\circ} \mathrm{C}$ for 30 days before being measured to determine the length of the vascular discoloration. Shoots of $V$. vinifera Cabernet Sauvignon and Carménère were included as reference hosts. Equal numbers of shoots were inoculated with sterile agar plugs as controls. Reisolations from the margins of the vascular lesions were performed on APDAm and incubated at $20^{\circ} \mathrm{C}$ for 14 days. The data were analyzed for variance according to a completely randomized design with 15 replicates and one shoot as the experimental unit. Means were subjected to Tukey's test $(P<0.05)$ using SigmaStat. The experiment was conducted twice.

\section{Results}

Field survey and symptoms. In longitudinal sections of cordons and trunks of young grapevines ( $<7$ years old), the symptoms were characterized only by the presence of BWS along the vascular tissues. In addition to BWS, brown to dark-brown hardwood decay and yellow softwood decay were found in older grapevines
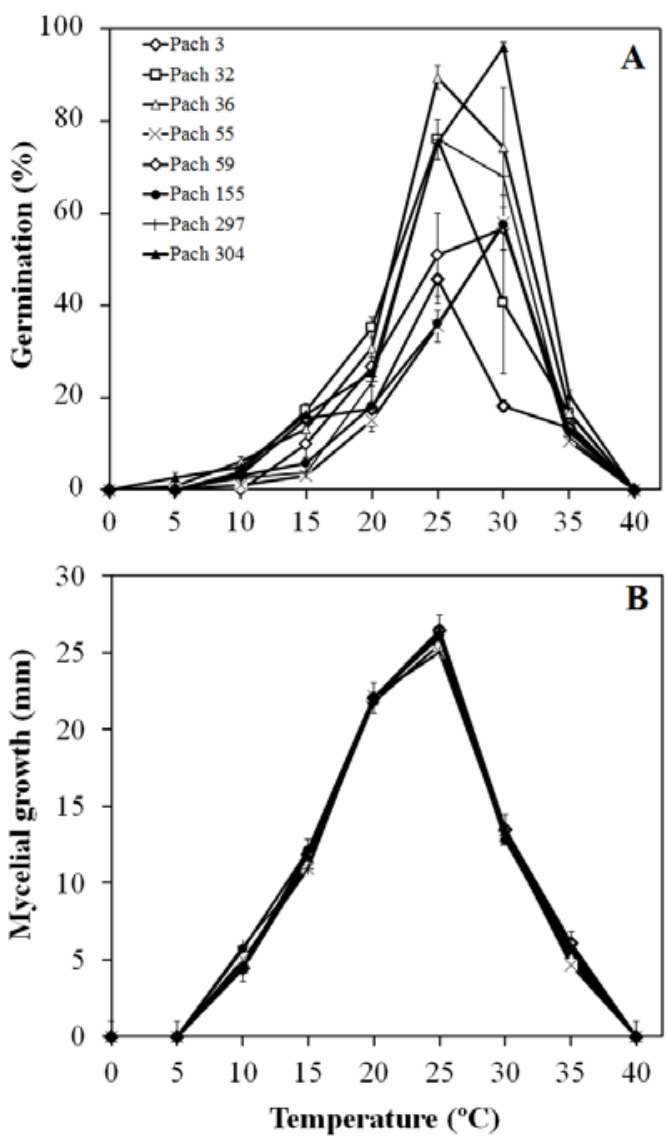

Fig. 3. Effect of temperature on conidial germination and mycelial growth of eight Chilean isolates of Phaeomoniella chlamydospora. A, Effect of temperature on conidial germination as determined after $24 \mathrm{~h}$ of incubation in vitro. B, Effect of temperature on mycelial growth as determined after 14 days on acidified potato dextrose agar media. Each point is the mean of four dates.
(>7 years old; Fig. 2A). The foliar symptoms that were associated with internal wood symptoms included a faint leaf chlorosis and yellow to red leaves in the white and red cultivars, respectively. Stunted growth, distorted leaves, and partial or total necrosis of the leaves were also observed.

P. chlamydospora was found in 58 of the 67 vineyards sampled, and was isolated from 590 of 694 cordons and trunk samples obtained from grapevines with trunk diseases (Table 3). In this study, $P$. chlamydospora was isolated in all the Chilean valleys that were surveyed except Copiapó Valley. P. chlamydospora was isolated alone from grapevines younger than 7 years old exhibiting BWS symptoms, and together with Botryosphaeriaceae spp. in grapevines older than 7 years (Fig. 2A; Table 3 ).

Of the 590 isolates of $P$. chlamydospora, $94.9 \%$ were from a BWS symptom, $4.4 \%$ were from the yellow softwood decay symptom, and $0.7 \%$ was from brown hardwood decay symptoms in grapevines with trunk diseases.

Spur symptoms were characterized by BWS extending along the vascular tissues in longitudinal sections (Fig. 2B). P. chlamydospora was isolated from 9 of $105(8.6 \%)$ spur samples from Cabernet Sauvignon $(4.8 \%)$ and Pinot Noir $(3.8 \%)$ vines that were examined in 2011 and 2012 (Table 3).

Isolation from nursery. From the nurseries, $P$. chlamydospora was identified in $19(12.6 \%)$ of 151 rooted cuttings from Cabernet Sauvignon (6.0\%), Chardonnay (2.6\%), and Pinot Noir $(4.0 \%)$ grapevines. The detection of $P$. chlamydospora was successful in 2010 (14.8\%), 2011 (12.3\%), and 2012 (8.0\%).

Potential inoculum sources. There was no evidence of $P$. chlamydospora in 168 grapevine pruning debris samples, 82 sap samples, 100 soil samples, or 293 weed samples that were collected from affected vineyards from 2010 to 2012 .

Morphological characterization. Isolates of $P$. chlamydospora were characterized by slow growth on MEA and APDA plates, with an estimated growth rate of 1.74 to $1.86 \mathrm{~mm} /$ day, respectively, in APDA at $25^{\circ} \mathrm{C}$. All isolates produced yeast-like colonies that were olivaceous to dark olivaceous with sparse aerial mycelium on APDA. On APDA, erect, nonbranched, smooth, and septated conidiophores were observed. The base of the conidiophores was subcylindrical, green-brown but hyline toward the tip at 15.7 to 52.1 by 1.7 to $3.2 \mu \mathrm{m}$. The conidia were unicellular, slightly pigmented, smooth, oblong to ellipsoidal, and 3.0 to 4.2 by 1.1 to 1.7 $\mu \mathrm{m}$. The conidia aggregated to form a slimy head at the conidiophore apex. Black-globose pycnidia were produced on pine needles and grapevine wood chips but the pycnidia were more abundant on grapevine wood chips. A dense white cirrus was observed on the pycnidia.

The isolates and temperatures had a significant $(P<0.001)$ effect on germination and the interaction between the isolate and temperature was also significant $(P<0.001)$. Conidia from the $P$. chlamydospora started to germinate after $24 \mathrm{~h}$ of incubation between 5 and $35^{\circ} \mathrm{C}$. The optimal germination occurred between 25 and $30^{\circ} \mathrm{C}$, depending on the isolate, and no germination was obtained at 0 or $40^{\circ} \mathrm{C}$ (Fig. 3A).

Mycelial growth was significantly affected by the specific isolates and temperatures $(P<0.001)$. The interaction between the isolate and temperature was significant $(P<0.001)$. The $P$. chlamydospora grew on APDA between 10 and $35^{\circ} \mathrm{C}$ regardless of the isolate, and there was no growth at 5 or $40^{\circ} \mathrm{C}$. No matter what isolate was chosen, $25^{\circ} \mathrm{C}$ was the optimum temperature for mycelial growth (Fig. 3B).

Canes remained alive during this experiment; however, shoot length and root length was considerably reduced in inoculated canes (data not shown). The BWS increased considerably when the conidial concentration increased from $10^{2}$ to $10^{7}$ conidia $/ \mathrm{ml}$. The inoculum concentration had a significant effect $(P<0.001)$ on the length of the BWS. A linear model $\left(y=2.8 \log x+0.01, R^{2}=0.96\right.$, $P<0.001)$ best explained the relationship between the log inoculum concentration and the length of the BWS that was obtained after 45 days at $20^{\circ} \mathrm{C}$. Regardless of the conidial concentration, $P$. chlamydospora was successfully reisolated from $85.4 \%$ of the 
inoculated samples. There was no evidence of $P$. chlamydospora in noninoculated controls.

Phylogenetic analyses. All of the amplified ITS and BT regions and sequences were nearly identical ( $>98 \%$ similarity) to reference sequences from $P$. chlamydospora. Chilean isolates of $P$. chlamydospora were deposited in GenBank (Table 1). The combined analysis of ITS and BT sequences revealed a phylogenetic tree that included two main clades, with Chilean isolates grouped together with isolates from the Unites States and South Africa in five subclades, with over $86 \%$ bootstrap support. Isolates from Spain were grouped separately, with $94 \%$ bootstrap support (Fig. 4). The MP analysis yielded one most parsimonious tree $(\mathrm{TL}=245$ steps, $\mathrm{CI}=$ $0.992, \mathrm{RI}=0.963$, and $\mathrm{RC}=0.956$ ).

Pathogenicity tests. $P$. chlamydospora isolates were pathogenic to the axenic grapevines that were inoculated with both conidia and mycelium. P. chlamydospora consistently induced $100 \%$ reddish leaf coloration in inoculated plantlets at 28 days after inoculation in both replicate experiments (Fig. 5A). The root length, shoot length, and number of leaves of inoculated plants were reduced significantly $(P<0.05)$ compared with those of the noninoculated controls (Table 4). P. chlamydospora was reisolated from $100 \%$ of the inoculated plantlets and from none of the noninoculated plants.

The conidia and mycelia from all tested P. chlamydospora isolates were pathogenic in grapevine spurs, inducing a BWS of 68.5 to 72.9 and 63.2 to $64.9 \mathrm{~mm}$, respectively, at 8 months post inoculation. The noninoculated spurs developed a slight discoloration of 10.0 to $12.9 \mathrm{~mm}$ which was significantly $(P=0.05)$ smaller than that of inoculated spurs (Table 5). The pathogen was recovered from 94.5 to $100 \%$ of inoculated spurs and from none of the noninoculated control spurs (Table 5).

All $P$. chlamydospora isolates induced BWS within the vascular tissues of inoculated shoots (Fig. 5D and F), with symptoms of
40.8 to $44.2 \mathrm{~mm}$ in length after 60 days under field conditions. Reisolations were successful in 91.7 to $97.2 \%$ of the inoculated shoots. The noninoculated shoots developed a slight discoloration of $8.7 \mathrm{~mm}$ that significantly $(P=0.05)$ differed from the inoculated shoots but the reisolations of $P$. chlamydospora were unsuccessful (Table 5).

Young grapevines that were inoculated with $P$. chlamydospora developed BWS symptoms of 81.8 to $90.9 \mathrm{~mm}$ in length after 15 months post inoculation under lath house conditions (Fig. 5C and E). Chlorotic and reddish leaf coloration was observed in $85.0 \%$ of the inoculated vines (Fig. 5B). Noninoculated young grapevines developed a slight discoloration of $9.9 \pm 1.5 \mathrm{~mm}$, and leaf reddening was not observed. The reisolations from inoculated young grapevines were $100 \%$ successful and $0 \%$ reisolations were obtained from the noninoculated controls (Table 5).

$P$. chlamydospora produced a black streak of 12.6 and 10.1 $\mathrm{mm}$ on detached shoots of $V$. champinii and $V$. riparia $\times V$. rupestris, respectively, independent of the isolates that were tested. The detached shoots of $V$. vinifera developed black streaking of 13.4 and $14.0 \mathrm{~mm}$ for Carménère and Cabernet Sauvignon, respectively. ANOVA detected significant differences $(P<0.001)$ between Vitis spp. but not among isolates $(P=0.5)$. The Vitis spp.-isolate interaction was not significant $(P=0.7)$. There were significant differences in the lengths of black streaking, with $V$. vinifera having larger levels than both $V$. champinii and $V$. riparia $\times V$. rupestris. The pathogen was recovered from $>56 \%$ of the inoculated shoots.

\section{Discussion}

On the basis of the morphological and molecular studies conducted in this work, $P$. chlamydospora was the main fungus that was isolated from BWS symptoms in Chilean V. vinifera. The

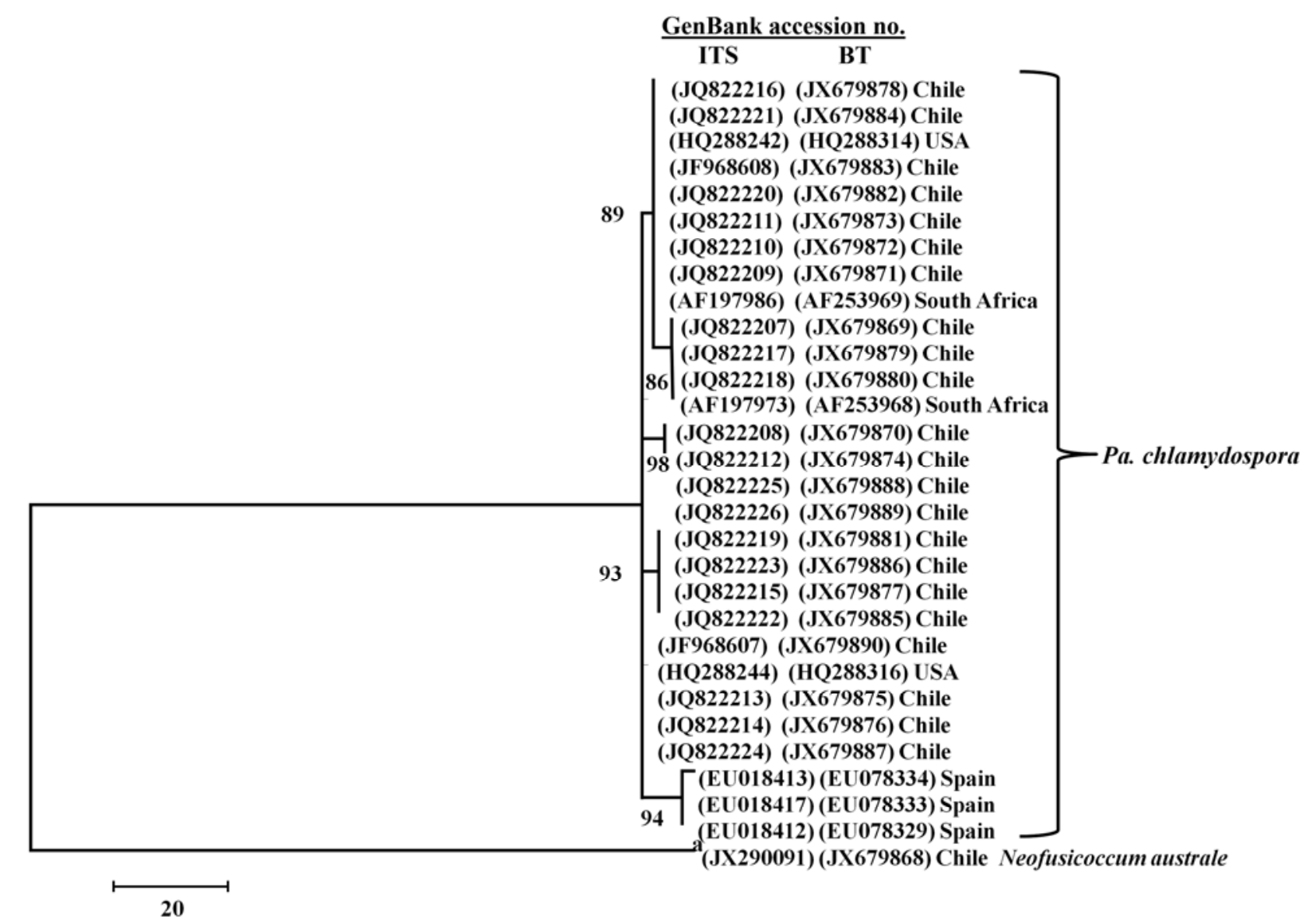

Fig. 4. One of five most parsimonious trees obtained from the combined internal transcribed spacer (ITS) and $\beta$-tubulin (BT) sequence data; tree length $=245$, consistency index $=0.992$, retention index $=0.963$, and rescaled consistency index $=0.956$. Bootstrap support values from 1,000 replicates $>50 \%$ are reported at the nodes. Values were obtained with Molecular Evolutionary Genetics Analysis version 5.0 software. 
BWS was the most prevalent vascular symptom to be observed in grapevines with trunk diseases, independent of the age of the grapevine. The characteristic foliar symptoms (stripe leaf patterns) of esca, which have been associated with $P$. chlamydospora in other studies $(16,40)$, were not observed in this study.

A
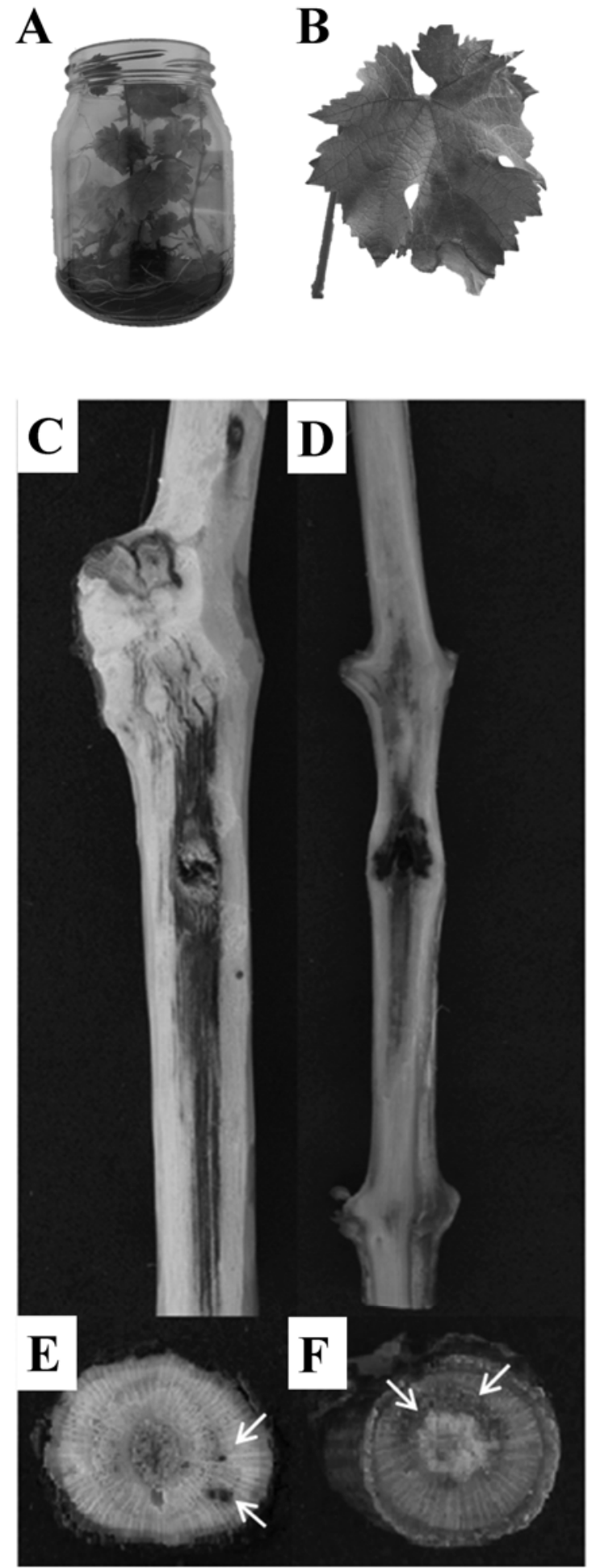

Fig. 5. Pathogenicity test of Phaeomoniella chlamydospora on grapevine. A, Inoculated 'Carménère' plantlets showed reddish leaves after 28 days. B, Inoculated young Carménère vines exhibited reddish leaves after 15 months. C, Inoculated young Carménère vine showed black wood-streaking lesions after 15 months. D, Inoculated 'Cabernet Sauvignon' shoots had black streaking lesions after 60 days. $\mathbf{E}$, Cross section of inoculated young Carménère vines revealed black points on the wood after 15 months. F, Cross section of inoculated Cabernet Sauvignon shoots had internal dark lesions after 60 days. White arrows indicate internal lesions in cross section.
P. chlamydospora was isolated from $94.9 \%$ of grapevines also with BWS symptoms. These samples were collected in vineyards located in sandy to clay soils in areas that were characterized by temperate conditions, with 1 to over $1,000 \mathrm{~mm}$ of annual rainfall. It is possible that deficit irrigation imposed after veraison to improve wine quality may exacerbate the impact of $P$. chlamydospora, as has been suggested in a study from South Africa (27). It is important to note that a relatively high level of isolation of $P$. chlamydospora from field samples may be due, in part, to our use of the semiselective medium containing $0.1 \%$ Igepal, which reduced contamination by faster-growing fungi.

Our findings are coincident with previous works, indicating that BWS symptoms are primarily associated with $P$. chlamydospora $(37,40,48)$. Interestingly, $P$. chlamydospora was isolated alone in a relative high frequency $(34.9 \%)$ from young grapevines showing BWS symptoms but other pathogens were co-isolated from mainly older grapevines, including species of Botryosphaeriaceae, Diatrypaceae, and Inocutis $(18,21)$.

As follows from this work, $P$. chlamydospora was always associated with BWS symptoms in young and mature grapevines, including nursery plants. Chilean isolates of $P$. chlamydospora were pathogenic, inducing black streaking in the shoots, spurs, and trunks of young vines ( $<7$ years old). Reisolations of P. chlamydospora from diseased tissues were successful, thereby fulfilling Koch's postulate. Furthermore, P. chlamydospora was pathogenic in axenic plantlets of Carménère grapevines, which were inoculated with conidia and mycelium that consistently induced leaf chlorosis, leaf reddening, stunted shoots, and eventual plant death. Although these leaf symptoms are not typical of $P$. chlamydospora infection, they may be due to the effect of toxins and vessel occlusion that limit the water supplied. A previous report has demonstrated that toxin production by $P$. chlamydospora is associated with foliar symptoms (2). Foliar symptoms were also induced in inoculated 2-year-old Carménère grapevines, suggesting that artificial infection with $P$. chlamydospora may result in symptoms similar to those observed in grapevines affected by BWS in the field.

As in this study, the pathogenicity of $P$. chlamydospora was reported in studies conducted in grapevine plantlets in vitro (29), and several reports have demonstrated that isolates of $P$. chlamydospora were pathogenic to grapevines and produced BWS symptoms in young grapevines, spurs, and cuttings $(5,8,15,19,25,26,35$, $37,38,40,44)$. In this study, a positive linear relationship was observed between the conidial concentration and the length of the vascular streaking in grapevine cuttings of Cabernet Sauvignon. Conidial concentrations as low as $10^{2}$ conidia/ml (two conidia per wound) were sufficient to induce symptoms, as previously suggested $(24,41)$, and further demonstrated the abilities of $P$. chlamydospora to induce BWS in young grapevine tissues.

Our results further demonstrate that $P$. chlamydospora was pathogenic in $V$. champini and $V$. riparia $\times V$. rupestris, coinciding with previous studies involving the cuttings of several Vitis spp. that were commonly used as rootstocks $(19,26)$. However, $P$. chlamydospora was not pathogenic in apple, pear, plum, and blueberry (data not shown). Therefore, P. chlamydospora appears to be a specific pathogen of Vitis spp. Although, recently, P. chlamydospora was isolated from olive and kiwifruit with symptoms of branch dieback $(23,49)$, and bindweed (1), the biological significance of these results remains to be determined. In this study, $P$. chlamydospora was always absent from bindweed and other weeds that were collected from infected vineyards.

Morphologically, the Chilean isolates of $P$. chlamydospora were similar and coincident with the original description of this species (16), except that the conidia were smaller than the size reported elsewhere $(12,37)$. A significant interaction between conidial germination and temperature was observed, with optimum temperatures varying between 25 and $30^{\circ} \mathrm{C}$, suggesting that considerable variation can occur in nature. The minimum $\left(10^{\circ} \mathrm{C}\right)$ and maximum $\left(35^{\circ} \mathrm{C}\right)$ temperatures for mycelial growth were in agreement with Tello et al. (46) but differed from other reports indicating optimal temperatures of 15 and $<35^{\circ} \mathrm{C}(16,54)$. 
The ITS analysis allowed a clear differentiation between $P$. chlamydospora and other Phaeomoniella spp. (17). The ITS phylogenetic analysis grouped Chilean isolates together with reference isolates in two subclades but, on the basis of the BT analysis, all $P$. chlamydospora were grouped in a single subclade (32). These results were similar to those reported by Cobos and Martin (13), and Comont et al. (14), who found a very low degree of genetic variation using amplified fragment length polymorphism markers and random amplified polymorphic DNA, respectively. However, the concatenated analysis of the ITS and BT grouped Chilean isolates with reference isolates from South Africa and the United States, and this group was separate from isolates from Spain. As such, there appears to be some intraspecific genetic variation in $P$. chlamydospora that corresponds to a geographic pattern. The lowlevel genetic diversity of $P$. chlamydospora may reflect the dominance of asexual reproduction in the field $(10,13,14,39,46)$.

In this study, there was no evidence for the presence of $P$. chlamydospora in soil, grapevine sap, or grapevine pruning debris. The absence of $P$. chlamydospora in the soil was coincident with the results of Rooney et al. (43) and they do not support the soilborne status suggested for this pathogen in other works $(33,42,53)$. However, considering that the isolation of viable propagules of $P$. chlamydospora from soil seems to be difficult, a different isolation technique must be used to provide definitive results. Other studies have identified $P$. chlamydospora from sap from girdling wounds, bark debris, and soil $(42,43)$. Nevertheless, additional studies are necessary to clarify the significance of these results.

As in previous reports $(4,34,42), P$. chlamydospora was detected in rooted cuttings from the nurseries. Therefore, it was postulated that infection can be initiated at the nursery, possibly from using contaminated plant material from infected mother plants, which suggests the importance of high-quality plant material $(28,31,50)$.

In summary, the results of the present study indicate that $P$. chlamydospora is highly associated with BWS symptoms in Chilean grapevines. This fungal pathogen was discovered for the first time in propagation material of grapevines from nurseries, suggesting that infected plants can play a role in the dispersal of BWS symptoms in Chilean grapevines.

\section{Acknowledgments}

Gonzalo A. Díaz thanks Conicyt for the scholarship given to pursue his postgraduate studies at the Pontificia Universidad Católica de Chile and for the financial support received through Conicyt project number 24120950. We thank K. Elfar, V. Escobar, R. Torres, and B. Puebla for their invaluable technical support; and V. Santa Rita and V. Veramonte for their support.

\section{Literature Cited}

1. Agustí-Brisach, C., Gramaje, D., León, M., García-Jiménez, J., and Armengol, J. 2011. Evaluation of vineyards weeds as potential host of black and petri disease pathogens. Plant Dis. 95:803-810.

2. Andolfi, A., Cimmino, A., Evidente, A., Iannaccone, M., Capparelli, R., Mugnai, L., and Surico, G. 2009. A new flow cytometry technique to identify Phaeomoniella chlamydospora exopolysaccharides and study mechanisms of esca grapevine foliar symptoms. Plant Dis. 93:680-684.

3. Armengol, J., Vicent, A., Torné, L., García-Figueres, F., and García-Jiménez, J. 2001. Fungi associated with esca and grapevine declines in Spain: a three-year survey. Phytopathol. Mediterr. 40:325-329.

4. Aroca, A., Gramaje, D., Armengol, J., García-Jiménez, J., and Raposo, R. 2010. Evaluation of the grapevine nursery propagation process as a source of Phaeoacremonium spp. and Phaeomoniella chlamydospora and occurrence of trunk disease pathogens in rootstock mother vine in Spain. Eur. J Plant Pathol. 126:165-174.

5. Aroca, A., and Raposo, R. 2009. Pathogenicity of Phaeoacremonium species on grapevine. J. Phytopathol. 157:413-419.

6. Auger, J., Aguilera, N., and Esterio, M. 2005. Identification of basidiomycete species associated with wood decay symptoms of grapevine chlorotic leaf roll in Chile. Phytopathol. Mediterr. 44:86-86.

7. Auger, J., Esterio, M., Ricke, G., and Pérez, I. 2004. Black dead arm and basal canker of Vitis vinifera cv. Red Globe caused by Botryosphaeria obtusa in Chile. Plant Dis. 88:1286-1286.

8. Auger, J., Pérez, I., Esterio, M., Gubler, W. D., and Eskalen, A. 2004. First report of Phaeomoniella chlamydospora on Vitis vinifera and French American hybrids in Chile. Plant Dis. 88:1285-1285.

Table 4. Pathogenicity of Phaeomoniella chlamydospora on axenic Vitis vinifera 'Carménère' plantlets after 28 days at $20^{\circ} \mathrm{C}$

\begin{tabular}{|c|c|c|c|c|c|}
\hline \multirow[b]{2}{*}{ Isolates } & \multicolumn{3}{|c|}{ Means $^{y}$} & \multirow[b]{2}{*}{ Reddish leaf (\%) } & \multirow[b]{2}{*}{ Reisolation $(\%)^{z}$} \\
\hline & Roots (mm) & Shoots $(\mathrm{mm})$ & Leaves (number) & & \\
\hline \multicolumn{6}{|c|}{ Mycelial inoculation } \\
\hline Pach-3 & $68.6 \pm 4.4 b$ & $68.6 \pm 6.2 b$ & $9.9 \pm 1.4 \mathrm{~b}$ & 100 & 100 \\
\hline Pach-32 & $63.4 \pm 6.1 \mathrm{~b}$ & $65.0 \pm 4.6 \mathrm{~b}$ & $9.5 \pm 2.4 \mathrm{~b}$ & 100 & 100 \\
\hline Pach-55 & $67.6 \pm 3.9 b$ & $67.9 \pm 3.4 b$ & $10.5 \pm 2.1 b$ & 100 & 100 \\
\hline Pach-297 & $64.6 \pm 5.5 b$ & $66.3 \pm 4.6 b$ & $9.9 \pm 1.6 b$ & 100 & 100 \\
\hline Control & $122.4 \pm 4.6 \mathrm{a}$ & $124.9 \pm 5.8 \mathrm{a}$ & $15.0 \pm 1.3 \mathrm{a}$ & 0 & 0 \\
\hline \multicolumn{6}{|c|}{ Conidial inoculation } \\
\hline Pach-3 & $68.2 \pm 5.3 b$ & $72.9 \pm 4.8 b$ & $7.4 \pm 0.7 b$ & 100 & 100 \\
\hline Pach-32 & $69.2 \pm 3.5 b$ & $70.7 \pm 4.5 b$ & $6.9 \pm 0.8 b$ & 100 & 100 \\
\hline Pach-55 & $68.1 \pm 7.2 b$ & $69.6 \pm 6.9 \mathrm{~b}$ & $6.8 \pm 1.1 b$ & 100 & 100 \\
\hline Pach-297 & $65.9 \pm 5.5 b$ & $67.7 \pm 4.7 b$ & $6.8 \pm 0.7 b$ & 100 & 100 \\
\hline Control & $118.1 \pm 5.9 \mathrm{a}$ & $123.4 \pm 6.5 \mathrm{a}$ & $13.4 \pm 0.9 \mathrm{a}$ & 0 & 0 \\
\hline
\end{tabular}

y Mean of eight plantlets \pm standard deviation. Means followed by the same letters in each column did not differ significantly according to Tukey's pairwise multiple comparison test $(P=0.05)$.

${ }^{\mathrm{z}}$ Percentage of samples from which the fungus was reisolated out of nine samples that were plated.

Table 5. Pathogenicity of Phaeomoniella chlamydospora causing black wood streaking in Vitis vinifera

\begin{tabular}{|c|c|c|c|c|c|c|c|c|}
\hline \multirow[b]{4}{*}{ Isolates } & \multicolumn{8}{|c|}{ Black wood streaking ${ }^{z}$} \\
\hline & \multicolumn{4}{|c|}{ 'Cabernet Sauvignon' spurs } & \multirow{2}{*}{\multicolumn{2}{|c|}{$\begin{array}{c}\text { 'Cabernet Sauvignon' shoots } \\
\text { Mycelia }\end{array}$}} & \multirow{2}{*}{\multicolumn{2}{|c|}{$\frac{\text { 'Carménère', young vine trunk }}{\text { Mycelia }}$}} \\
\hline & \multicolumn{2}{|c|}{ Mycelia } & \multicolumn{2}{|c|}{ Conidia } & & & & \\
\hline & $\begin{array}{c}\text { Length } \\
(\mathrm{mm})\end{array}$ & $\begin{array}{c}\text { Reisolation } \\
(\%)\end{array}$ & $\begin{array}{l}\text { Length } \\
(\mathrm{mm})\end{array}$ & $\begin{array}{c}\text { Reisolation } \\
(\%)\end{array}$ & $\begin{array}{l}\text { Length } \\
(\mathrm{mm})\end{array}$ & $\begin{array}{c}\text { Reisolation } \\
(\%)\end{array}$ & $\begin{array}{l}\text { Length } \\
(\mathrm{mm})\end{array}$ & $\begin{array}{c}\text { Reisolation } \\
(\%)\end{array}$ \\
\hline Pach-3 & $72.9 \pm 1.4 \mathrm{a}$ & 100 & $63.2 \pm 2.7 \mathrm{a}$ & 94.5 & $44.2 \pm 2.5 \mathrm{a}$ & 97.2 & $90.9 \pm 5.8 \mathrm{a}$ & 100 \\
\hline Pach-32 & $69.7 \pm 2.9 \mathrm{a}$ & 97.2 & - & - & $41.4 \pm 3.0 \mathrm{a}$ & 94.5 & $87.8 \pm 6.1 \mathrm{a}$ & 100 \\
\hline Pach-55 & $70.8 \pm 3.7 \mathrm{a}$ & 97.2 & $64.9 \pm 1.8 \mathrm{a}$ & 97.2 & $40.8 \pm 2.7 \mathrm{a}$ & 91.7 & $81.8 \pm 5.5 \mathrm{a}$ & 100 \\
\hline Pach-297 & $68.5 \pm 2.9 \mathrm{a}$ & 97.2 & - & - & $41.4 \pm 3.3 \mathrm{a}$ & 94.5 & $83.0 \pm 2.3 \mathrm{a}$ & 100 \\
\hline Control & $10.0 \pm 1.6 b$ & 0 & $12.9 \pm 1.3 b$ & 0 & $8.7 \pm 1.1 b$ & 0 & $9.9 \pm 1.5 b$ & 0 \\
\hline
\end{tabular}

${ }^{\mathrm{z}}$ Length: means followed by the same letters in each column did not differ significantly according to Tukey's pairwise multiple comparison test $(P=0.05)$; \pm standard deviation. Reisolation: percentage of samples from which the fungus was reisolated out of 180,108 and 45 samples from spurs, shoots and young vines, respectively. 
9. Besoain, X., Torres, C., Díaz, G. A., and Latorre, B. A. 2013. First report of Neofusicoccum australe associated with Botryosphaeria canker of grapevine in Chile. Plant Dis. 97:143-143.

10. Borie, B., Jacquiot, L., Jamaux-Desprèaux, I., Larignon, P., and Péros, J. P. 2002. Genetic diversity in populations of the fungi Phaeomoniella chlamydospora and Phaeoacremonium aleophilum on grapevine in France. Plant Pathol. 51:85-96.

11. Briceño, E. X., and Latorre, B. A., 2008. Characterization of Cladosporium rot in grapevines, a problem of growing importance in Chile. Plant Dis. 92:1635-1642.

12. Chicau, G., Aboim-Inglez, M., Cabral, S., and Cabral, J. P. S. 2000. Phaeoacremonium chlamydosporum and Phaeoacremonium angustius associated with esca and grapevine decline in vinho verde grapevines in northwest Portugal. Phytopathol. Mediterr. 39:80-86.

13. Cobos, R., and Martin, M. T. 2008. Molecular characterization of Phaeomoniella chlamydospora isolated from grapevines in Castilla y León (Spain). Phytopathol. Mediterr. 47:20-27.

14. Comont, G., Corio-Costet, M. F., Larignon, P., and Delmotte, F. 2010. AFLP markers reveal two genetic groups in the French population of the grapevine fungal pathogen Phaeomoniella chlamydospora. Eur. J. Plant Pathol. 127:451-464.

15. Cortesi, P., Fischer, M., and Milgroom, M. G. 2000. Identification and spread of Fomitiporia punctata associated with wood decay of grapevine showing symptoms of esca. Phytopathology 90:967-972.

16. Crous, P., and Gams, W. 2000. Phaeomoniella chlamydospora gen. et comb. nov., a causal organism of petri grapevine decline and esca. Phytopathol. Mediterr. 39:112-118.

17. Damm, U., Fourie, P. H., and Crous, P. W. 2010. Coniochaeta (Lecythophora), Collophora gen. nov. and Phaeomoniella species associated with wood necroses of Prunus trees. Persoonia 24:60-80.

18. Díaz, G. A., Auger, J., Besoain, X., Bordeu, E., and Latorre, B. A. 2013. Prevalence and pathogenicity of fungi associated with trunk diseases in Chilean vineyards. Cienc. Invest. Agrar. 40:327-339.

19. Díaz G.A. Esterio, M., and Auger, J. 2009. Effects of Phaeomoniella chlamydospora and Phaeoacremonium aleophilum on grapevine rootstocks. Cienc. Invest. Agrar. 36:381-390.

20. Díaz, G. A., and Latorre, B. A. 2011. Identification of fungi associated with trunk diseases of grapevine (Vitis vinifera) in Chile. (Abstr.) Phytopathology 101:S42.

21. Díaz, G. A., and Latorre, B. A. 2013. Efficacy of paste and liquid fungicide formulation to protect pruning wounds against pathogens associated with grapevine trunk diseases. Crop Prot. 46:106-112.

22. Díaz, G. A., Prehn, D., Besoain, X., Chávez, E. R., and Latorre. B. A. 2011. Neofusicoccum parvum associated with grapevine trunk diseases in Chile. Plant Dis. 95:1032-1032.

23. Di Marco, S., Calzarano, F., Gams, W., and Cesari, A. 2000. A new wood decay of kiwifruit in Italy. N. Z. J. Crop Hortic. Sci. 28:69-72.

24. Elena, G., García-Figueres, F., and Luque, J. 2012. The minimum inoculum potential of Diplodia seriata and Phaeomoniella chlamydospora needed for the artificial infection of grapevine pruning wounds. (Abstr.) Phytopathol. Mediterr. 51:434.

25. Eskalen, A., Feliciano, A. J., and Gubler, W. D. 2007. Susceptibility grapevine pruning wounds and symptoms development in response to infection by Phaeoacremonium aleophilum and Phaeomoniella chlamydospora. Plant Dis. 91:1100-1104

26. Eskalen, A., Gubler, W. D., and Khan, A. 2001. Rootstock susceptibility to Phaeomoniella chlamydospora and Phaeoacremonium spp. Phytopathol. Mediterr. 40:S433-S438.

27. Ferreira, J. H. S., van Wyk, P. S., and Calitz, F. J. 1999. Slow dieback of grapevine in South Africa: stress-related predisposition of young vines for infection by Phaeoacremonium chlamydosporum. S. Afr. J. Enol. Vitic. 20:43-46.

28. Fourie, P. H., and Halleen, F. 2006. Chemical and biological protection of grapevine propagation material from trunk disease pathogens. Eur. J. Plant Pathol. 116:255-265.

29. Gatica, M., Dubos, B., and Larignon, P. 2000. The 'hoja de malvón' grape disease in Argentina. Phytopathol. Mediterr.39:41-45.

30. Glass, N. L., and Donaldson, G. C. 1995. Development of primer set designed for use with the PCR to amplify conserved genes from filamentous ascomycetes. Appl. Environ. Microbiol. 61:1323-1330.

31. Gramaje, D., and Armengol, J. 2011. Fungal trunk pathogens in the grapevine propagation process: potential inoculum source, detection, identifica- tion, and management strategies. Plant Dis. 95:1040-1055.

32. Groenewald, M., Kang, J.-C., Crous, P. W., and Gams, W. 2001. ITS and $\beta$-tubulin phylogeny of Phaeoacremonium and Phaeomoniella species. Mycol. Res. 105:651-657.

33. Gubler, W. D., Baumgartner, K., Browne, G. T., Eskalen, A., Rooney Latham, S., Petit, E., and Bayramian, L. A. 2004. Roots diseases of grapevines in California and their control. Australas. Plant Pathol. 33:157-165.

34. Halleen, F., Crous, P. W., and Petrini, O. 2003. Fungi associated with healthy grapevine cuttings in nurseries, with special reference to pathogens involved in the decline of young vines. Australas. Plant Pathol. 32:47-52.

35. Hallen, F., Mostert, L., and Crous, P. W. 2007. Pathogenicity testing of lesser-known vascular fungi of grapevines. Australas. Plant Pathol. 36:277285.

36. Khan, A., Whiting, C., Rooney, S., and Gubler, W. D. 2000. Pathogenicity of three Phaeoacremonium spp. on grapevine in California. Phytopathol. Mediterr. 39:92-99.

37. Larignon, P., and Dubos, B. 1997. Fungi associated with esca disease in grapevine. Eur. J. Plant Pathol. 103:147-157.

38. Laveau, C., Letouze, A., Louvet, G., Bastien, S., and Guérin-Dubrana, L. 2009. Differential aggressiveness of fungi implicated in esca and associated diseases of grapevine in France. Phytopathol. Mediterr. 48:32-46.

39. Mostert, L., Abeln, E. C. A., Halleen, F., and Crous, P. W. 2006. Genetic diversity among isolates of Phaeomoniella chlamydospora on grapevines. Australas. Plant Pathol. 35:453-460.

40. Mugnai, L., Graniti, A., and Surico, G. 1999. esca (black measles) and brown wood-streaking: two old and elusive diseases of grapevines. Plant Dis. 83:404-418.

41. Reed, A. B., Melton, L. D., Smith, B. G., and Johnston, P. 2005. The influence of Phaeomoniella chlamydospora and other fungi on the strength of the graf union and biosmass of young grapevine. (Abstr.) Phytopathol. Mediterr. 44:100-101.

42. Retief, E., McLeod, A., and Fourie, P. H. 2006. Potential inoculum sources of Phaeomoniella chlamydospora in South African grapevine nurseries. Eur. J. Plant Pathol. 115:331-339.

43. Rooney, S., Eskalen, A., and Gubler, W. D. 2001. Recovery of Phaeomoniella chlamydospora and Phaeoacremonium inflatipes from soil and grapevine tissues. Phytopathol. Mediterr. 40:S351-S356.

44. Scheck, H., Vasquez, S., Fogle, D., and Gubler, W. D. 1998. Tree Phaeo acremonium spp. cause young grapevine in California. Plant Dis. 82:590.

45. Tamura, K., Petersen, D., Petersen, N., Stecher, G., Nei, M., and Kumar, S. 2011. Molecular evolutionary genetics analysis using maximum likelihood evolutionary distance, and maximum parsimony methods. Mol. Biol. Evol. 28:2731-2739.

46. Tello, M. L., Gramaje, D., Gómez, A., Abad-Campos, P., and Armengol, J. 2010. Analysis of phenotypic and molecular diversity of Phaeomoniella chlamydospora isolates in Spain. J. Plant Pathol. 92:195-203.

47. Úrbez-Torres, J. R. 2011. The status of Botryosphaeriaceae species infecting grapevines. Phytopathol. Mediterr. 50:S5-S44.

48. Úrbez-Torres, J. R., Peduto, F., Striegler, R. K., Urrea-Romero, K. E., Rupe J. C., Cartwrigth, R. D., and Gubler, W. D. 2012. Characterization of funga pathogens associated with grapevine trunk diseases in Arkansas and Missouri. Fungal Divers. 52:169-189.

49. Úrbez-Torres, J. R., Peduto, F., Vossen, P. M., Krueger, W. H., Gubler, W. D. 2013. Olive twig and branch dieback: etiology, incidence, and distribution in California. Plant Dis. 97:231-244.

50. Waite, H., and Morton, L. 2007. Hot water treatment, trunk diseases and other critical factors in the production of high-quality grapevine planting material. Phytopathol. Mediterr. 46:5-7.

51. White, C. L., Halleen, F., and Mostert, L. 2011. Symptoms and fungi associated with esca in South African vineyards. Phytopathol. Mediterr. 50:S236-S246.

52. White, T. J., Bruns, T., Lee, S., and Taylor, J. 1990. Amplification and direct sequencing of fungal ribosomal RNA genes for phylogenetics. Pages 315-322 in: PCR, A Guide to Methods and Applications. M. A. Innis, D. H. Gelfand, J. J. Snisky, and T. J. White, eds. Academic Press, San Diego, CA

53. Whiteman, S. A., Jaspers, M. V., Stewart, A., and Ridgway, H. J. 2002 Detection of Phaeomoniella chlamydospora in soil using species-specific PCR. N. Z. Plant Prot. 55:139-145.

54. Whiting, E. C., Khan, A., and Gubler, W. D. 2001. Effect of temperature and water potential on survival and mycelial growth of Phaeomoniella chlamydospora and Phaeoacremonium spp. Plant Dis. 85:195-201. 